\title{
Pemanfaatan Barang Bekas Sebagai Media Alat Peraga Sederhana Dalam Upaya Meningkatkan Aktivitas dan Hasil Belajar Biologi
}

\author{
Erwing $^{* 1}$, Andi Kurniawati Ahmad ${ }^{2}$ \\ ${ }^{1}$ Universitas Muhammadiyah Bone \\ ${ }^{2}$ Madrasah Aliyah Negeri 2 Bone \\ Email: ${ }^{1}$ ewinkijo26@gmail.com, ${ }^{2}$ kurniahmad@gmail.co.id
}

\begin{abstract}
Abstrak
Penelitian ini adalah penelitian tindakan kelas ( Classroom Action Research ) penelitian ini bertujuan untuk meningkatkan aktivitas dan hasil belajar biologi siswa melalui Pemanfaatan Barang Bekas Sebagai Media Alat Peraga Sederhana, dengan pemberian tugas terstruktur, subjek penelitian ini adalah siswa kelas X Mipa3 Man 2 Bone Kabupaten Bone, yang berjumlah 36 orang. penelitian ini dilaksanakan dalam dua siklus, yang terdiri dari empat kali pertemuan. Adapun prosedur setiap siklus berlangsung empat tahap, yaitu: (1) perencanaan, (2) pelaksanaan tindakan, (3) observasi, dan ( refleksi ). teknik pengumpulan yang digunakan pada penelitian ini yaitu tentang hasil belajar yang diambil dengan tes pada akhir setiap siklus, data aktivitas siswa diambil dengan cara menggunakan lembar observasi, pada saat pembelajaran berlangsung. Teknik analisis data yang digunakan adalah teknik analisis data deskriptif kuantitatif. Berdasarkan hasil penelitian pembahasan selama dua siklus maka dapat disimpulkan bahwa aktivitas siswa kelas X MIPA3 MAN 2 Bone Kabupaten Bone, mengalami peningkatan pada setiap pertemuan siklus I dan Siklus II atau berada pada criteria baik. Sedangkan untuk hasil belajar biologi siswa juga mengalami peningkatan dari siklus I dan Siklus II. Hal ini di tunjukkan oleh (1) meningkatnya jumlah siswa yang mencapai KKM dari siklus I ke Siklus II yaitu 15 siswa pada siklus I menjadi 30 siswa pada siklus II. Dengan demikian Pemanfaatan Barang Bekas Sebagai Media Alat Peraga Sederhana dengan pemberian tugas terstruktur dapat Meningkatkan Aktivitas Dan Hasil Belajar Biologi Kelas X Mipa3 MAN 2 Bone Kabupaten Bone.
\end{abstract}

Kata kunci: Aktivitas, Belajar, Media Alat Peraga Sederhana, Tugas Terstruktur

\section{Utilization of Used Goods as Simple Teaching Aids in an Effort to Increase Biology Activities and Learning Outcomes}

\begin{abstract}
This research is a class action research (Classroom Action Research). This research aims to increase the activities and learning outcomes of students' biology through the use of used goods as simple teaching aids, by giving structured assignments, the subjects of this study were students of class X Mipa3 Man 2 Bone, Bone Regency., which numbered 36 people. This research was conducted in two cycles, consisting of four meetings. The procedure for each cycle lasts four stages, namely: (1) planning, (2) implementing the action, (3) observation, and (reflection). The collection technique used in this study is about the learning outcomes taken with a test at the end of each cycle, student activity data is taken by using an observation sheet, when learning takes place. The data analysis technique used is descriptive quantitative data analysis techniques. Based on the results of the discussion research for two cycles, it can be concluded that the activities of class X Mipa3 Man 2 Bone Bone Regency have increased at each meeting of cycle I and cycle II or are in good criteria. Meanwhile, students' learning outcomes for biology also increased from cycle I and cycle II. This is shown by (1) the increase in the number of students who reach the KKM from cycle I to cycle II, namely 15 students in cycle I to 30 students in cycle II. Thus the use of used goods as a simple teaching aid by giving structured assignments can increase the activity and learning outcomes of biology class X Mipa3 Man 2 Bone, Bone regency
\end{abstract}

Keywords: Activities, Learning, Simple Teaching Aids, Structured Assignments

\section{PENDAHULUAN}

Pendidikan adalah suatu hal yang sangat penting bagi kehidupan manusia. sejak manusia menghendaki kemajuan dalam kehidupan, sejak itulah timbul gagasan untuk melakukan pengalihan, pelestarian, dan 
pengembangan kebudayaan melalui pendidikan. Oleh karena itu dalam sejarah pertumbuhan masyarakat,pendidikan senantiasa menjadi perhatian utama dalam rangka memajukan kehidupan generasi sejalan dengan tuntutan masyarakat[1].

Pada hakikatnya guru dapat mencari alternatif lain sebagai pendukung proses belajar mengajar agar dapat terlaksana dengan baik, karena pembelajaran biologi menuntut guru untuk aktif dan kreatif dalam menciptakan berbagai media pembejaran walau hanya media sederhana apabila media tersebut belum tersedia. Apabila guru kreatif, sangat banyak alternatif yang dapat digunakan untuk menciptakan media atau alat peraga sederhana dan murah guna memenuhi kebutuhan pembelajaran[2]. Maka alat peraga bahan bekas dapat menjadi solusi alternatif dalam mendukung proses pembelajaran materi pencemaran lingkungan, khususnya di kelas X MIPA3 MAN 2 Bone Kabupaten Bone.

Brubacher mengatakan bahwa pendidikan adalah proses pengembangan potensi, kemampuan, dan kapasitas manusia yang mudah dipengaruhi oleh kebiasaan, kemudian disempurnakan dengan kebiasaan- kebiasaan baik, didukung dengan alat (media) yang disusun sedemikian rupa, sehingga pendidikan dapat digunakan untuk menolong orang lain atau dirinya sendiri dalam mencapai tujuan-tujuan yang telah ditetapkan[3].

Komponen pendidikan yang paling penting yang dikemukakan Wiji adalah tujuan, peserta didik, pendidik, alat (media) dan lingkungan. Jika salah satu komponen tidak ada, maka proses pendidikan tidakakan bisa dilaksanakan dengan baik[4]. Hasil pendidikan yang berupa perubahan tingkah laku meliputi bentuk kemampuan yang menurut taksonomi Bloom diklasifikasikan dalam tiga kemampuan (domain) yaitu kognitif, afektif dan psikomotor.

Berdasarkan observasi di sekolah MAN 2 Bone kabupaten bone masih ada kekurangan yang ditemukan yaitu hasil belajar biologi, Dimana nilai ketuntasannya (KKM) yaitu 65 yang telah ditentukan oleh sekolah yang bersangkutan. Sedangkan sekitar $70 \%$ siswa yang hasil belajar biologinya bisa dikatakan masih berada pada kategori kurang, ini disebabkan karena, siswa kurang aktif dalam pembelajaran, siswa jarang mengajukan pertanyaan karena kurang percaya diri, siswa kurang fokus memperhatikan pembelajaran yang berlangsung sehingga kurang memahami setiap materi dalam pelajaran biologi. khususnya di kelas X MIPA3, kurangnya minat belajar siswa dalam pelajaran biologi merupakan hal yang perlu diperhatikan sebagai bahan atau acuan untuk meningkatkan hasil belajar siswa terhadap materi pelajaran sehingga dapat ditindak lanjuti oleh guru kedepannya.

\section{METODE PENELITIAN}

Penelitian ini adalah penelitian tindakan kelas (Classroom Action Research) yang merupakan penelitian yang bersifat praktis dan bertujuan untuk memperbaiki kekurangan-kekurangan dalam pembelajaran dikelas dengan cara melakukan tindakan-tindakan dalam upaya perbaikan kinerja[5]. Penelitian tindakan kelas ini terdiri dari tahap perencanaan tindakan, pelaksanaan tindakan, evaluasi dan refleksi. Penelitian ini dilaksanakan di MAN 2 BONE pada bulan April-Mei 2019 yang terletak di Kabupaten Bone Tahun Pelajaran 2019/2020 dan yang menjadi subjek adalah siswa kelas X yang jumlah 36 orang. Penelitian tindakan kelas ini dilaksanakan sebanyak dua siklus. Tiap siklus dilakukan perubahan sesuai dengan tujuan yang ingin dicapai. Secara rinci pelaksanaan penelitian untuk dua siklus ini yaitu siklus I sebanyak dua kali pertemuan dan siklus II sebanyak dua kali pertemuan. Kedua siklus ini merupakan rangkaian kegiatan yang saling berkaitan.

Teknik pengumpulan data pada penelitian ini adalah tes pilihan ganda yang diberikan untuk mengetahui hasil belajar siswa. Tes hasil belajar akan dikembangkan oleh peneliti yang berjumlah 20 ( dua puluh) nomor. Setiap pertanyaan dilengkapi lima pilihan. Nilai untuk setiap jawaban yang benar adalah lima, sedangkan jawaban yang salah mendapatkan nilai 0. Data yang terkumpul melalui instrument penelitian berupa data hasil belajar siswa, data hasil observasi aktivitas belajar siswa. Pengolahan data kualitatif akan diolah menggunakan analisis statistik deskriptif. Analisis ini bertujuan untuk menggambarkan kegiatan belajar mengajar, kendalakendala yang dihadapi dan hasil belajar siswa selama peneliti melaksanakan penelitian.

Data analisis hasil belajar siswa dalam pembelajaran biologi dihitung dengan menentukan rata-rata dan persentase ketuntasan hasil belajar siswa dalam penelitian, digunakan analisis dengan prosedur sebagai berikut [6]:

$$
\mathrm{x}=\sum X
$$

Keterangan :

$\mathrm{X}=$ Rata-rata

$\sum X=$ Jumlah dari skor-skor (nilai-nilai) yang ada

$\mathrm{n} \quad=$ Number of cases (jumlah data) 


\section{HASIL DAN PEMBAHASAN}

Pada bagian ini akan di deskripsikan penelitian tentang aktivitas dan hasil belajar siswa setelah pelaksanaan pembelajaran biologi menggunakan pemanfaatan barang bekas sebagai media alat peraga sederhana yang di laksanakan dalam dua siklus, dimana siklus pertama berlangsung selama dua kali pertemuan dan siklus kedua yang berlangsung selama dua kali pertemuan.

\subsection{Hasil Observasi Aktivitas Belajar Siswa Siklus I}

Pada siklus I, peneliti mengadakan observasi terhadap aktivitas siswa saat proses pembelajaran dengan pemanfaatan barang bekas sebagai media pembelajaran alat peraga sederhana pada siswa kelas X MIPA3 MAN 2 Bone Kabupaten Bone materi pencemaran lingkungan, diamati dengan menggunakan lembar observasi, dimana pada lembar observasi terdiri dari 6 indikator, penelitian aktivitas belajar siswa di lakukan peneliti sebagai observer. Adapun acuan yang di gunakan untuk mengamati atau menilai aktivitas belajar siswa, terdiri dari beberapa kategori yaitu, Sangat Baik (SB) bobot 5, Baik (B) bobot 4, Cukup (C) bobot 3 dan, Kurang (K) bobot 2 .

Pada pertemuan pertama, perolehan persentase aktivitas belajar siswa sebesar $66.94 \%$ dengan kriteria baik, selanjutnya pada pertemuan kedua prolehan persentase aktivitas siswa meningkat yaitu $67,78 \%$ dengan kriteria baik.

Hal ini menunjukkan bahwa perlu adanya siklus II untuk melakukan perbaikan, sehingga mampu meningkatkan aktivitas belajar peserta didik.

\subsection{Hasil Belajar Siswa}

Analisis deskriptif skor hasil belajar biologi materi pencemaran lingkungan pada siswa kelas X MIPA3 MAN 2 Bone Kabupaten Bone dengan pemanfaatan barang bekas sebagai media alat peraga sederhana dapat sebagai berikut :

Tabel 1. Hasil Belajar Biologi Siswa Pada Tes Siklus I (Sumber : Data Olahan, 2020)

\begin{tabular}{cc}
\hline Uraian & Skor \\
\hline Jumlah Siswa & 36 \\
Skor Maksimum & 100 \\
Skor Tertinggi & 85 \\
Skor Terendah & 35 \\
Skor Minimum & 0 \\
Rata - Rata & 57.78 \\
\hline
\end{tabular}

Apabila skor belajar biologi siswa di kelompokkan dalam lima kategori, sesuai dengan kategori yang di tetapkan oleh Departemen Pendidikan Nasional, maka di peroleh distribusi frekuensi dan persentase hasil belajar biologi siswa kelas X MIPA3 MAN 2 Bone Kabupaten Bone seperti di bawah berikut ini :

Tabel 2. Distribusi Frekuensi dan Persentase Skor Hasil Belajar Siklus I (Data Olahan, 2020)

\begin{tabular}{cccc}
\hline Kategori & Interval Nilai & Frekuensi & Persentase \\
\hline Sangat Tinggi & $85-100$ & 5 & $13.89 \%$ \\
Tinggi & $65-84$ & 10 & $27.78 \%$ \\
Sedang & $55-64$ & 7 & $19.44 \%$ \\
Rendah & $35-54$ & 14 & $38.89 \%$ \\
Sangat rendah & $0-34$ & 0 & $0 \%$ \\
\hline Jumlah & & 36 & $100 \%$ \\
\hline
\end{tabular}

Adapun hasil balajar biologi siswa pada siklus I apabila di tinjau dari tingkat ketuntasan belajar, dapat dilihat pada tabel persentase ketuntasan belajar siswa berikut dibawah ini.

Tabel 3. Persentase Ketuntasan Belajar Biologi Siswa Siklus I (Data Olahan, 2020)

\begin{tabular}{cccc}
\hline Kategori & Skor & Frekuensi & Persentase \\
\hline Tuntas & $\geq 65$ & 15 & $41.67 \%$ \\
Tidak Tuntas & $\leq 65$ & 21 & $58.33 \%$ \\
\hline Jumlah & & 36 & $100 \%$ \\
\hline
\end{tabular}




\subsection{Refleksi Siklus I}

Hasil persentase ketuntasan belajar siswa pada siklus I menunjukkan bahwa siswa yang berada pada kategori tuntas sebesar $41.67 \%$, dan siswa yang berada pada kategori tidak tuntas sebesar 58.33\%. Hal tersebut menunjukkan bahwa hasil belajar siswa belum mencapai ketuntasan klasikal yang telah di tetapkan. Menyikapi hal tersebut, maka bentuk refleksi yang akan di lakukan adalah meningkatkan hasil belajar siswa dengan cara, lebih mendorong dan memotivasi siswa agar lebih aktif dalam pembelajaran, dan meningkatkan kebranian siswa untuk berperan aktif dalam kelompok.

\subsection{Hasil Observasi Aktivitas Belajar Siswa Siklus II}

Pada siklus II, peneliti mengadakan observasi terhadap aktivitas siswa saat proses pembelajaran dengan pemanfaatan barang bekas sebagai media pembembelajaran alat peraga sederhana pada siswa kelas X MIPA3 MAN 2 Bone Kabupaten Bone materi pencemaran lingkungan, diamati dengan menggunakan lembar observasi.

Dapat di lihat bahwa perolehan persentase aktivitas belajar siswa untuk setiap pertemuan pada siklus II mengalami peningkatan. Pada pertemuan pertama, perolehan persentase aktivitas belajar siswa sebesar $75.83 \%$ dengan kriteria baik, selanjutnya pada pertemuan kedua prolehan persentase aktivitas siswa meningkat yaitu 93,47\% dengan kriteria sangat baik, peningkatan yang terjadi pada siklus II sebesar 17.64\%.

\subsection{Hasil Belajar Siswa}

Adapun analisis deskriptif skor hasil belajar biologi materi pencemaran lingkungan pada siswa kelas $\mathrm{X}$ MIPA3 MAN 2 Bone Kabupaten Bone dengan pemanfaatan barang bekas sebagai media alat peraga sederhana dapat dilihat.

Tabel 4. Hasil Belajar Biologi Siswa Pada Tes Siklus II (Sumber : Data Olahan, 2020)

\begin{tabular}{cc}
\hline Uraian & Skor \\
\hline Jumlah Siswa & 36 \\
Skor Maksimum & 100 \\
Skor Tertinggi & 90 \\
Skor Terendah & 40 \\
Skor Minimum & 0 \\
Rata - Rata & 70 \\
\hline
\end{tabular}

Apabila skor belajar biologi siswa di kelompokkan dalam lima kategori, sesuai dengan kategori yang di tetapkan oleh Departemen Pendidikan Nasional, maka di peroleh distribusi frekuensi dan persentase hasil belajar biologi siswa kelas X MIPA3 MAN 2 Bone Kabupaten Bone seperti pada tabel di bawah ini.

Tabel 5. Distribusi Frekuensi dan Persentase Skor Hasil Belajar Siklus II (Data Olahan, 2020)

\begin{tabular}{cccc}
\hline Kategori & Interval Nilai & Frekuensi & Persentase \\
\hline Sangat Tinggi & $85-100$ & 8 & $22.22 \%$ \\
Tinggi & $65-84$ & 22 & $61.11 \%$ \\
Sedang & $55-64$ & 0 & $0 \%$ \\
Rendah & $35-54$ & 6 & $16.67 \%$ \\
Sangat rendah & $0-34$ & 0 & $0 \%$ \\
\hline Jumlah & & 36 & $100 \%$ \\
\hline
\end{tabular}

Dapat di lihat bahwa dari 36 siswa yang menjadi subjek penelitian, siswa yang berada pada kategori sangat rendah sebanyak 0 siswa atau dengan persentase sebanyak 0\%, kategori rendah sebanyak 6 siswa atau dengan persentase sebanyak $16.67 \%$, kategori sedang sebanyak 0 siswa atau dengan persentase sebanyak $0 \%$, kategori tinggi sebanyak 22 siswa atau dengan persentase sebanyak $61.11 \%$, kategori sangat tinggi sebanyak 8 siswa atau dengan persentase sebanyak $22.22 \%$.

Adapun hasil balajar biologi siswa pada siklus II apabila di tinjau dari tingkat ketuntasan belajar, dapat dilihat pada tabel persentase ketuntasan belajar siswa berikut dibawah ini. 
Tabel 6. Persentase Ketuntasan Belajar Biologi Siswa Siklus II (Data Olahan, 2020)

\begin{tabular}{cccc}
\hline Kategori & Skor & Frekuensi & Persentase \\
\hline Tuntas & $\geq 65$ & 30 & $83.33 \%$ \\
Tidak Tuntas & $\leq 65$ & 6 & $16.67 \%$ \\
\hline Jumlah & & 36 & $100 \%$ \\
\hline
\end{tabular}

\subsection{Refleksi Siklus II}

Setelah melakukan observasi maka tahap selanjutnya adalah refleksi. hasil observasi pada siklus II menunjukka, bahwa setelah diadakan tindakan dengan menggunakan media alat peraga sederhana dengan pemberian tugas terstruktur pada pembelajaran biologi, materi pencemaran lingkungan, aktivitas belajar siswa mengalami peningkatan, hal ini dapat dilihat dari perbandingan aktivitas belajar siswa pada awal pembelajaran yang masi pasif kemudian mengalami peningkatan menjadi aktif.

\section{PEMBAHASAN}

Berdasarkan analisis deskriptif hasil observasi siswa kelas X MIPA3 MAN 2 Bone Kabupaten Bone, di ketahui aktivitas siswa dari siklus I ke siklus II mengalami peningkatan dapat dilihat pada lampiran 5 dan lampiran 6, pada pertemuan pertama siklus I, perolehan aktivitas belajar siswa sebesar $66.94 \%$ dengan kriteria baik, selanjutnya pada pertemuan kedua prolehan persentase aktivitas siswa meningkat yaitu 67,78\% dengan kriteria baik. Sedangkan perolehan persentase aktivitas belajar siswa untuk setiap pertemuan pada siklus II ,Pada pertemuan pertama, perolehan persentase aktivitas belajar siswa sebesar $75.83 \%$ dengan kriteria baik, selanjutnya pada pertemuan kedua prolehan persentase aktivitas siswa meningkat yaitu 93,47\% dengan kriteria sangat baik.

Selain peningkatan terhadap aktivitas belajar siswa, hasil belajar siswa kelas X MIPA3 MAN 2 Bone Kabupaten Bone, juga mengalami peningkatan. Berdasarkan analisis deskriptif hasil belajar siswa kelas X MIPA3 MAN 2 Bone Kabupaten Bone, diketahui hasil belajar siswa dari siklus I ke siklus II mengalami peningkatan, diketahui nilai rata-rata yang diperoleh siswa pada siklus I adalah 57.78, dengan skor tertinggi 85 dan skor terendah 35 sedangkan diketahui nilai rata-rata yang diperoleh siswa pada siklus II adalah70, dengan skor tertinggi 90 dan skor terendah 40, hal ini menunjukkan bahwa nilai rata-rata hasil belajar biologi siswa materi pencemaran lingkungan mengalami peningkatan dengan pemberian tugas terstruktur.

\section{KESIMPULAN}

Berdasarkan hasil penelitian dan pembahasan, maka dapat disimpulkan bahwa penerapan pemanfaatan barang bekas sebagai media alat peraga sederhana dengan pemberian tugas terstruktur dapat meningkatkan aktivitas belajar siswa kelas X MIPA3 MAN 2 Bone Kabupaten Bone. Hal ini dapat dilihat dari adanya peningkatan pada setiap indikator aktivitas siswa pada setiap pertemuan dari siklus I ke siklus II. Penerapan pemanfaatan barang bekas sebagai media alat peraga sederhana dengan pemberian tugas terstruktur dapat meningkatkan hasil belajar biologi siswa kelas X MIPA3 MAN 2 Bone Kabupaten Bone, terbukti dengan adanya peningkatan jumlah siswa yang memperoleh nilai $\geq 65$ ( KKM ). Jumlah siswa yang mencapai KKM pada siklus I sebanyak 15 siswa dengan persentase sebesar $41.67 \%$. Pada siklus II sebanyak 30 siswa dengan persentase sebesar $83.33 \%$, terjadi peningkatan sejumlah 15 siswa dengan persentase sebesar $41.67 \%$.

\section{DAFTAR PUSTAKA}

[1] M. Arifin, “Ilmu Pendidikan Islam,” Bumi Aksara : Jakarta, 2006.

[2] A. Abdullah, W. Oviana, \& H. Khatimah, "Penggunaan Alat Peraga dari Bahan Bekas dalam Menjelaskan Sistem Respirasi Manusia di MAN Sawang Kabupaten Aceh Selatan," Jurnal Biologi Edukasi, vol. 3, no. 2, pp 51-55, 2011.

[3] Burhanuddin, "Supervisi Pendidikan Dan Pengajaran," Rasido: Malang, 2007

[4] S. Wiji, "Dasar-Dasar Ilmu Kependidikan,” Ar-Ruzz: Yogyakarta, 2006.

[5] S. Arikunto, "Prosedur Penelitian, Suatu Pendekatan Praktik, " Rineka Cipta: Jakarta, 2014

[6] Rizki, "Meningkatkan Aktivitas Dan Hasil Belajar Matematika Melalui Strategi Pembelajaran Keep On Learning Dengan Pemberian Tugas Terstruktur Kelas VIII 2 SMP Negri 2 Buluppodo," Skripsi : Studi Pendidikan matematika STKIP Muhammadiyah Bone, 2017. 